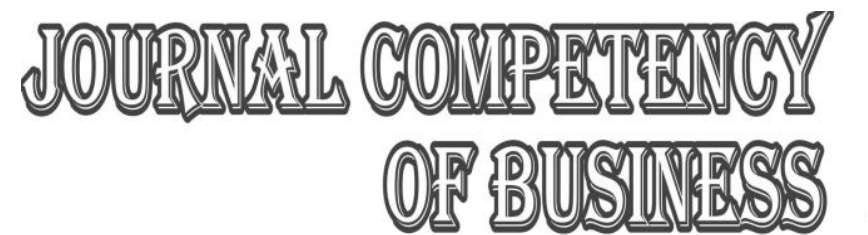

\title{
ANALISIS PENGARUH KERAGAMAN PRODUK, PERSEPSI HARGA DAN LOKASI TERHADAP MINAT BELI ULANG MELALUI BRAND IMAGE PADA KONSUMEN ROCKET CHICKEN
}

\author{
Henny Welsa ${ }^{1}$, Ignatius Soni Kurniawan ${ }^{2}$, Risang Nagar $^{3}$ \\ Fakultas Ekonomi Universitas Sarjanawiyata Tamansiswa Yogyakarta \\ 15oni_kurniawan@ustjogja.ac.id, ${ }^{2}$ risangnagar96@gmail.com
}

\begin{abstract}
ABSTRAK
Penelitan ini bertujuan untuk mengetahui pengaruh keragaman produk, persepsi harga, dan lokasi terhadap minat beli ulang melalui variabel intervening brand image pada pelanggan Rocket Chicken. Populasi dalam penelitian adalah 100 pembeli Rocket Chicken. Teknik pengambilan sampel dalam penelitian ini adalah dengan kuisioner online melalui Google Formulir yang dibagikan secara random kepada pelanggan Rocket Chicken. Hasil menunjukan antara keragaman produk dan persepsi harga memiliki pengaruh signifikan terhadap brand image dengan masing-masing nilai signifikasi adalah 0,000 dan 0,017 yang mana lebih kecil dari 0,05 , kemudian untuk lokasi yang memiliki nilai signifikan diatas 0,05 yaitu 0,316 tidak memiliki pengaruh signifikan terhadap brand image. Nilai signifikan brand image dan lokasi terhadap minat beli ulang adalah 0,000 dan 0,002 dimana nilai signifikan dibawah 0,05 berarti kedua variabel ini memiliki pengaruh pengaruh yang positif terhadap minat beli ulang, sedangkan pada variabel keragaman produk dan persepsi harga yang nilai signifikannya terhadap minta beli ulang adalah 0,098 dan 0,245 tidak memiliki pengaruh signifikan terhadap minat beli ulang.
\end{abstract}

Kata kunci: keragaman produk, persepsi harga, lokasi, brand image, minat beli ulang, pengaruh

\section{ABSTRACT}

This study aims to determine the effect of product diversity, price perception, and location on repurchase intention through the intervening variable brand image on Rocket Chicken customers. The population in the study were 100 Rocket Chicken buyers. The sampling technique in this study was an online questionnaire via Google Forms which was distributed randomly to Rocket Chicken customers. The results show that product diversity and price perception have a significant effect on brand image with each significance value of 0.000 and 0.017 which is smaller than 0.05, then for locations that have a significant value above 0.05, namely 0.316, it does not have a significant effect. to brand image. Significant values of

E-ISSN: 2777-1156

2021. Vol 5. No 1 


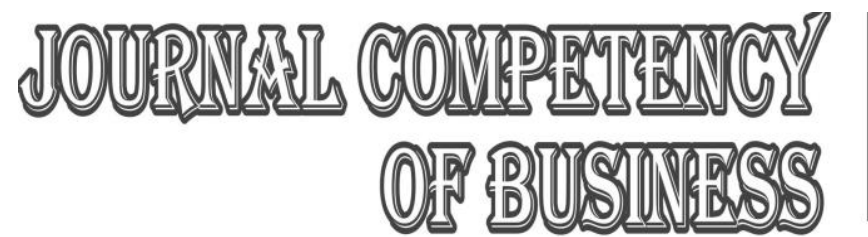

Fakultas Ekonomi, Universitas Cokroaminoto Yogyakarta

brand image and location on repurchase intention are 0.000 and 0.002 where a significant value below 0.05 means that these two variables have a positive influence on repurchase intention, while product diversity and price perception have a significant value on repurchase requests. are 0.098 and 0.245 have no significant effect on repurchase interest.

Keywords: product diversity, price perception, location, brand image, repurchase intention influence

\section{PENDAHULUAN}

Pada era globalisasi persaingan antara pelaku bisnis khususnya bidang kuliner menjadi semakin ketat dalam menarik perhatian dan minat konsumen. Menjamurnya usaha kuliner mengharuskan pelaku bisnis untuk meningkatkan daya saing penjualan agar tidak mengalami gulung tikar. Salah satu bisnis kuliner yang saat ini sedang berkembang pesat di masyarakat adalah bisnis franchise.

Bisnis franchise pada dunia kuliner dibedakan menjadi dua, yaitu franchise minuman dan franchise makanan. Untuk franchise minuman yang biasa ditemui di masyarakat adalah thai tea, poci, chatime. Sedangkan untuk bisnis franchise makanan yang sering ditemui adalah franchise bisnis ayam goreng yaitu Rocket Chicken, Olive Chicken, dan Popeye. Hampir disetiap jalan atau tempat-tempat strategis pasti kita akan menemukan bisnis franchise. Oleh karena itu, usaha franchise yang memiliki jenis usaha yang sama harus memiliki keunggulan agar dapat menarik minat beli konsumen.

Rocket Chicken adalah Perusahaan kemitraan yang bergerak di Bidang Fast Food Restaurant, dengan produk unggulan Fried chicken, Burger, Steak dan Chinese food (https://rocketchicken.co.id/about/) dikutip tanggal 27 Oktober 2020). Rocket Chicken didirikan oleh Nurul Atik dan berdiri sejak Februari 2010.

Semakin banyaknya usaha franchise membuat persaingan antara pengusaha franchise semakin ketat. Salah satu franchise yang masih sangat digemari masyarakat adalah Rocket Chicken. Ada banyak faktor yang mempengaruhi eksistensi dari bisnis Rocket Chicken. Penelitian ini bertujuan untuk mengetahui pengaruh Keragaman Harga, Persepsi harga, dan lokasi terhadap minat beli ulang pembeli makanan Rocket Chicken melalui mediator Brand Image.

E-ISSN: 2777-1156

2021. Vol 5. No 1 


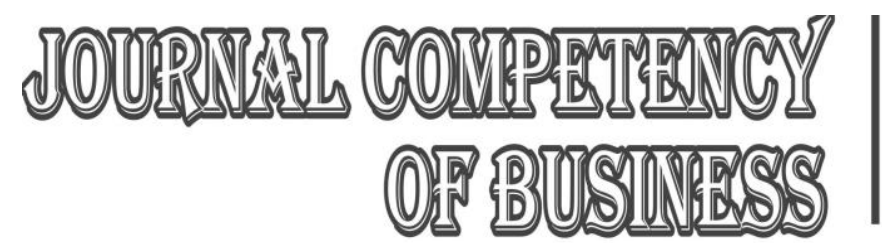

\section{KAJIAN PUSTAKA}

\section{Keragaman Produk}

Kotler \& Keller (Tjiptono dan Chandra, 2012:274) mendefinisikan produk sebagai segala sesuatu yang bisa ditawarkan untuk memenuhi kebutuhan dan keinginan konsumen. Jadi, produk bisa mencakup aspek fisik (tangible, seperti bentuk, warna, fitur, dan sebagainya) maupun non-fisik (intangible, seperti citra, reputasi, dan seterusnya).

Sedangkan Menurut Keegan (Tjiptono dan Chandra, 2012:274), produk merupakan kumpulan berbagai atribut fisik, psikologis, jasa/layanan, dan simbolik yang secara kolektif membentuk kepuasan atau manfaat bagi para pembeli atau pemakai. Kemudian keragaman produk atau diversifikasi produk diartikan sebagai suatu usaha penganekaragaman sifat dan fisik, barang atau jasa yang dihasilkan oleh perusahaan untuk digunakan konsumen di dalam memuaskan kebutuhannya.

\section{Persepsi Harga}

Xia et al. pada Lee dan Lawson-Body (2011: 532) mengemukakan bahwa persepsi harga merupakan penilaian konsumen dan bentuk emosional yang terasosiasi mengenai apakah harga yang ditawarkan oleh penjual dan harga yang dibandingkan dengan pihak lain masuk diakal, dapat diterima atau dapat dijustifikasi. Gourville dan Moon pada Toncaret al. (2010:297) menyatakan bahwa persepsi harga konsumen dipengaruhi oleh harga yang ditawarkan oleh toko lain dengan barang yang sama.

\section{Lokasi}

Menurut Heizer dan Render (2015), Lokasi memiliki kekuasaan untuk membuat strategi bisnis perusahaan sehingga lokasi merupakan pendorong biaya dan pendapatan pada perusahaan, sehingga lokasi yang tepat akan menguntungkan bagi perusahaan, sebaliknya lokasi yang kurang tepat dapat menurunkan efektifitas perusahaan.

E-ISSN: 2777-1156 
Fakultas Ekonomi, Universitas Cokroaminoto Yogyakarta

Lokasi bagi sebuah usaha pertokoan seperti bisnis franchise merupakan suatu masalah yang sangat penting karena pemilihan lokasi yang strategis dapat menimbulkan minat beli konsumen dan keberhasilan dalam menentukan lokasi akan memberikan kontra prestasi terhadap perusahaan yaitu naiknya tingkat penjualan dan laba konsumen dalam membeli barang tidak semata-mata hanya mendapatkan barang yang dibutuhkan dengan harga yang wajar dan kualitas yang baik sesuai dengan yang diharapkan tetapi juga cenderung melihat beberapa aspek pendukung seperti lokasi toko tersebut (George Slauss dalam penelitian Kurniawan, 2012:5)

\section{Brand Image}

Supranto dan Limakrisna (2011) menyatakan citra merek adalah apa yang konsumen pikir dan rasakan ketika mendengar atau melihat suatu merek dan apa yang konsumen pelajari tentang merek. Sehingga dapat disimpulkan bahwa citra merek adalah sekumpulan asosiasi merek yang dapat konsumen rasakan dan dipikirkan yang diciptakan dan dipelihara oleh pemasar agar terbentuk di dalam benak konsumen. Kotler dan Armstrong (2012:80) menyatakan "brand image adalah himpunan keyakinan konsumen mengenai berbagai merek". Brand image atau brand description merupakan deskripsi tentang asosiasi dan keyakinan konsumen terhadap merek tertentu. Sebuah produk dapat melahirkan sebuah brand jika produk itu menurut persepsi konsumen mempunyai keunggulan fungsi (functional brand), menimbulkan asosiasi dan citra yang diinginkan konsumen (brand image) dan membangkitkan pengalaman tertentu saat konsumen berinteraksi dengannya (experiental brand).

\section{Minat Beli Ulang}

Menurut Nurhayati dan Murti (2012) minat pembelian ulang adalah kenginan dan tindakan konsumen untuk membeli ulang suatu produk, karena adanya kepuasan yang diterima sesuai yang dinginkan dari suatu produk. Ketika suatu produk dapat memenuhi kepuasan pelanggan maka hal tersebut dapat mempengaruhi pelanggan untuk melakukan pembelian ulang terhadap suatu produk.

E-ISSN: 2777-1156

2021. Vol 5. No 1 
Fakultas Ekonomi, Universitas Cokroaminoto Yogyakarta

Timbulnya minat pembelian ulang didasari atas kepercayaan konsumen terhadap produk yang ditawarkan oleh perusahaan hal ini selaras dengan pendapat Simamora dalam Hamka (2010:2) yang menyatakan minat beli suatu produk timbul karena adanya dasar kepercayaan terhadap produk yang pemasaran dan jajaran luas faktor lain, perusahaan yang dapat mencapai dan mempertahankan diferensiasi akan menjadi perusahaan berkinerja di atas rata-rata dalam industry seandainya premi harganya melebihi biaya ekstra yang diperlukan untuk menjadi unik.

\section{Pengembangan Hipotesis}

Keragaman produk atau diversifikasi produk diartikan sebagai suatu usaha penganekaragaman sifat dan fisik, barang atau jasa yang dihasilkan oleh perusahaan untuk digunakan konsumen di dalam memuaskan kebutuhannya. Jika toko menyediakan produk yang beranekaragam, akan lebih memudahkan pebisnis toko untuk menarik konsumen agar berkunjung di tempatnya. Karena, semakin banyaknya pilihan yang disediakan oleh toko, maka akan semakin memudahkan konsumen untuk memilih produk sesuai keinginannya. Agustina (2017) menyatakan semakin beragam produknya, konsumen akan semakin puas dalam memilih produk. Dampak dari kepuasan inilah yang akan memberikan dampak positif terhadap citra merek, sehingga merek akan selalu diingat oleh konsumen. Berdasarkan pemaparan tersebut hipotesis yang diajukan sebagai berikut :

H1: Keragaman produk berpengaruh positif terhadap brand image pada konsumen Rocket Chicken

Kaitannya persepsi harga dengan brand image, penelitian yang dilakukan oleh Rizki Ananda, dkk (2015) mengungkapkan bahwa persepsi harga berpengaruh positif dan signifikan terhadap citra merek atau brand image karena Harga yang ditawarkan oleh adidas lebih rendah dari kompetitor dekatnya dan hal ini akan menimbulkan persepsi harga yang baik di mata konsumen maka akan meningkatkan citra merek adidas.

H2: Persepsi harga berpengaruh positif terhadap brand image pada konsumen Rocket Chicken

Lokasi adalah segala sesuatu yang berhubungan dengan lokasi fisik dan aktivitas barang termasuk toko/ kantor/ pabrik, dan metode distribusi yang digunakan untuk mengirim

E-ISSN: 2777-1156

2021. Vol 5. No 1 
Fakultas Ekonomi, Universitas Cokroaminoto Yogyakarta

barang keterangan pelanggan. Pilihan lokasi sangat penting bagi setiap bisnis, dan merupakan kunci segala aspek pemasaran bagi eceran atau bisnis jasa. Hotman, dkk (2017) mengindikasikan bahwa semakin baik lokasi maka semakin tinggi minat beli konsumen, hal ini tentunya berkaitan dengan keinginan konsumen yang meningkat untuk memiliki produk dari suatu merek.

H3: Lokasi berpengaruh positif terhadap brand image pada konsumen Rocket Chicken

Ida ayu, dkk (2018) berpendapat bahwa semakin baik citra merek yang dimiliki produk kosmetik merek Oriflame, maka akan semakin tinggi pula kepuasan pelanggan. Kepuasan adalah salah satu faktor terpenting yang diinginkan pelanggan atau konsumen dari sebuah pembelian produk. Apabila konsumen mendapatkan kepuasan terhadap suatu produk yang dibeli maka minat untuk melakukan pembelian ulang akan meningkat.

H4: Brand Image berpengaruh positif terhadap minat beli ulang pada konsumen Rocket Chicken

Jika toko menyediakan produk yang beranekaragam, akan lebih memudahkan pebisnis toko untuk menarik konsumen agar berkunjung di tempatnya. Karena, semakin banyaknya pilihan yang disediakan oleh toko, maka akan semakin memudahkan konsumen untuk memilih produk sesuai keinginannya. Kaitannya dengan minat pembelian ulang dikutip dari Agustina (2017) yang menyatakan semakin beragam produknya, konsumen akan semakin puas dalam memilih produk. Apabila konsumen merasakan kepuasan dalam pembelian suatu produk, maka akan meningkatkan keinginan untuk melakukan pembelian ulang terhadap suatu produk. Berdasarkan pemaparan tersebut hipotesis yang diajukan sebagai berikut :

H5: Keragaman produk berpengaruh positif terhadap minat beli ulang pada konsumen Rocket Chicken

Persepsi harga merupakan penilaian konsumen dan bentuk emosional yang terasosiasi mengenai apakah harga yang ditawarkan oleh penjual dan harga yang dibandingkan dengan pihak lain masuk diakal, dapat diterima atau dapat dijustifikasi. Ida ayu, dkk (2018) berpendapat bahwa penawaran harga yang terjangkau dan menarik dengan kualitas produk

E-ISSN: 2777-1156

2021. Vol 5. No 1 


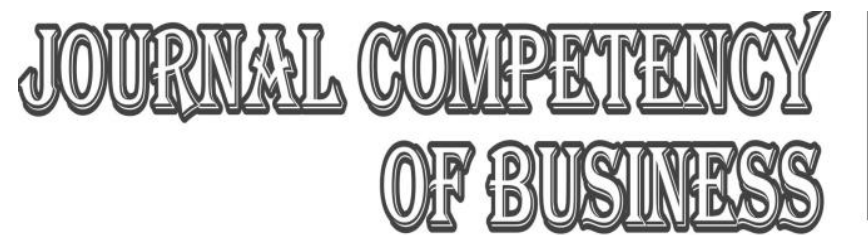

Fakultas Ekonomi, Universitas Cokroaminoto Yogyakarta

yang bagus mampu menciptakan kepuasan pelanggan. Hal ini tentunya akan memberikan persepsi harga yang baik bagi konsumen sehingga akan meningkatkan minat pembelian ulang terhadap suatu produk oleh konsumen.

H6: Persepsi harga berpengaruh positif terhadap minat beli ulang pada konsumen Rocket Chicken

Lokasi adalah segala sesuatu yang berhubungan dengan lokasi fisik dan aktivitas barang termasuk toko/ kantor/ pabrik, dan metode distribusi yang digunakan untuk mengirim barang keterangan pelanggan. Pilihan lokasi sangat penting bagi setiap bisnis, dan merupakan kunci segala aspek pemasaran bagi eceran atau bisnis jasa. Hotman, dkk (2017) mengindikasikan bahwa semakin baik lokasi maka semakin tinggi minat beli konsumen. Dimana lokasi usaha yang baik dan mudah dijangkau akan mempengaruhi minat konsumen untuk membeli ulang suatu produk atau barang. Berdasarkan pemaparan tersebut hipotesis yang diajukan sebagai berikut :

H7: Lokasi berpengaruh positif terhadap minat beli ulang pada konsumen Rocket Chicken

\section{METODE PENELITIAN}

Penelitian ini adalah penelitian yang bersifat kuantitatif. Metode kuantitatif adalah penelitian ilmiah yang sistematis terhadap bagian-bagian dan fenomena serta hubunganhubungannya. Tujuan penelitian kuantitatif adalah mengembangkan dan menggunakan model-model matematis, teori-teori dan hipotesis yang berkaitan dengan fenomena alam. Penelitian ini dilakukan dengan tujuan untuk menggambarkan suatu keadaan obyek tertentu yang memiliki hubungan atau dipengaruhi oleh faktor lain dan penarikan kesimpulannya didasarkan pada angka yang diolah secara statistik. Penelitian ini dilakukan terhadap konsumen atau pelanggan makanan cepat saji Rocket Chicken.

\section{HASIL ANALISIS DAN PEMBAHASAN}

Item uji validitas dikatakan valid jika nilai $r$ hitung $\geq \mathrm{r}$ tabel (0.1966). Pengujian menghasilkan $r$ hitung untuk keragaman produk (0,566 sd 0,793), Persepsi harga (0,798 sd

E-ISSN: 2777-1156

2021. Vol 5. No 1 
Fakultas Ekonomi, Universitas Cokroaminoto Yogyakarta

0,912), Lokasi (0,628 sd 0,855), brand image (0,609 sd 0,780), dan minat beli ulang (0,688 sd 0,787) yang mana semua variabel memiliki nilai $r$ hitung $>\mathrm{r}$ tabel $(0,1966)$ sehingga dikatakan valid. Nilai Cronbanch alpha Keragaman produk $(0,880)$, persepsi harga $(0,931)$, Lokasi $(0,919)$, brand image (0.807), dan minat beli ulang (0.878) yang mana lebih besar dari $(>0,6)$ maka variabel dikatakan valid.

Tabel 1. Karakteristik Responden

\begin{tabular}{lcc}
\hline \multicolumn{1}{c}{ Kategori } & Jumlah & Presentase \\
\hline Jenis kelamin & & \\
\hline Laki-Laki & 28 & 28 \\
\hline Perempuan & 72 & 72 \\
\hline Usia & 31 & 31 \\
\hline $15-20$ & 50 & 50 \\
\hline $21-25$ & 15 & 15 \\
\hline $26-30$ & 3 & 3 \\
$31-35$ & 1 & 1 \\
\hline$>35$ & & \\
\hline Pendidikan Terakhir & 0 & 0 \\
\hline SD/MI & 4 & 4 \\
\hline SMP/MTS & 48 & 48 \\
\hline SMA/MA/SMK & 6 & 6 \\
\hline D1-D3 & 41 & 41 \\
\hline S1 & 1 & 1 \\
\hline S2 & & \\
\hline Pekerjaan & 49 & 49 \\
\hline Pelajar/Mahasiswa & 13 & 13 \\
\hline PNS/TNI/POLRI & 5 & 5 \\
\hline Buruh & 19 & 19 \\
\hline Swasta & 12 & 12 \\
\hline Wiraswasta & 2 & 2 \\
\hline Lainnya & & \\
\hline
\end{tabular}

Karakteristik responden (Tabel 1) dalam penelitian ini menunjukkan responden laki-laki (28\%) lebih banyak dibandingkan perempuan (72\%). Mayoritas responden berusia 21-25 tahun (50\%), sedangkan berdasar tingkat pendidikan terakhir, mayoritas adalah lulusan SMA/SMK (48\%) diikuti lulusan S1 (41\%). Sebagian besar responden adalah pelajar (49\%) .

E-ISSN: 2777-1156

2021. Vol 5. No 1 


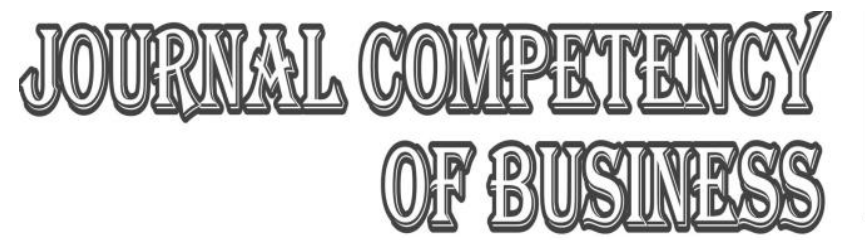

Tabel 2. Uji Multikolinearitas

\begin{tabular}{llc}
\hline \multicolumn{1}{c}{ Variabel } & Tolerance & VIF \\
\hline Keragaman Produk (X1) & 0.298 & 3.354 \\
\hline Persepsi Harga (X2) & 0.373 & 2.682 \\
\hline Lokasi (X3) & 0.399 & 2.504
\end{tabular}

Dari tabel 2 dapat disimpulkan bahwa variabel X1, X2, dan X3 diketahui nilai tolerance lebih besar dari 0.10, kemudian untuk nilai VIF untuk variabel X1, X2, dan X3 adalah <10.00 maka dapat disimpulkan bahwa tidak terjadi gejala multikolinearitas dalam model regresi.

Tabel 3. Hasil Uji Hipotesis

\begin{tabular}{|c|c|c|c|c|c|}
\hline \multirow[b]{3}{*}{ Model } & \multicolumn{2}{|c|}{ Coefficients $^{\mathrm{a}}$} & \multirow[b]{2}{*}{$\begin{array}{l}\text { Standardized } \\
\text { Coefficients }\end{array}$} & \multirow[b]{3}{*}{$\mathrm{t}$} & \multirow[b]{3}{*}{ Sig. } \\
\hline & \multicolumn{2}{|c|}{ Unstandardized Coefficients } & & & \\
\hline & B & Std. Error & Beta & & \\
\hline 1 (Constant) & 6.031 & 1.718 & & 3.511 & .001 \\
\hline Keragaman Produk (X1) & .445 & .076 & .590 & 5.857 & .000 \\
\hline Persepsi Harga (X2) & .204 & .084 & .219 & 2.432 & .017 \\
\hline Lokasi (X3) & .054 & .053 & .088 & 1.008 & .316 \\
\hline
\end{tabular}

a. Dependent Variable: Brand Image (Y)

Berdasarkan tabel 3 di atas diperoleh hasil sebagai berikut:

1. Ada pengaruh positif yang signifikan antara variabel keragaman produk terhadap brand image dengan nilai signifikansi $0,000<0,05$.

2. Ada pengaruh positif yang signifikan antara variabel persepsi harga terhadap brand image dengan nilai signifikansi $0,017<0,05$.

3. Ada pengaruh negative yang signifikan antara variabel lokasi produk terhadap brand image dengan nilai signifikansi $0,316>0,05$.

E-ISSN: 2777-1156

2021. Vol 5. No 1 
Tabel 4. Hasil Uji Hipotesis

Coefficients $^{\mathrm{a}}$

\begin{tabular}{|l|r|r|r|r|r|}
\hline \multirow{2}{*}{ Model } & \multicolumn{2}{|c|}{ Unstandardized Coefficients } & Standardized Coefficients & & \multicolumn{1}{c|}{ Sig. } \\
\cline { 2 - 6 } & \multicolumn{1}{|c|}{$\mathrm{B}$} & Std. Error & Beta & .550 & .583 \\
\hline 1 Constant) & 1.135 & 2.062 & & & \\
& .167 & .100 & .198 & 1.669 & .098 \\
Keragaman Produk (X1) & -.114 & .098 & -.110 & -1.169 & .245 \\
Persepsi Harga (X2) & .189 & .060 & .277 & 3.129 & .002 \\
Lokasi (X3) & .594 & .115 & .531 & 5.148 & .000 \\
Brand Image (Y) & & & & \\
\hline
\end{tabular}

a. Dependent Variable: Minat Beli Ulang $(\mathrm{Z})$

Berdasarkan tabel 4 di atas diperoleh hasil sebagai berikut:

1. Ada pengaruh negatif yang signifikan antara variabel keragaman produk terhadap minat beli ulang dengan nilai signifikansi $0.098>0,05$.

2. Ada pengaruh negative yang signifikan antara variabel persepsi harga terhadap minat beli ulang dengan nilai signifikansi $0.245>0,05$.

3. Ada pengaruh positif yang signifikan antara variabel lokasi produk terhadap minat beli ulang dengan nilai signifikansi $0.002<0,05$.

4. Ada pengaruh positif yang signifikan antara variabel brand image terhadap minat beli ulang dengan nilai signifikansi $0.000<0,05$.

E-ISSN: 2777-1156 


\section{Uji Sobel Tes}

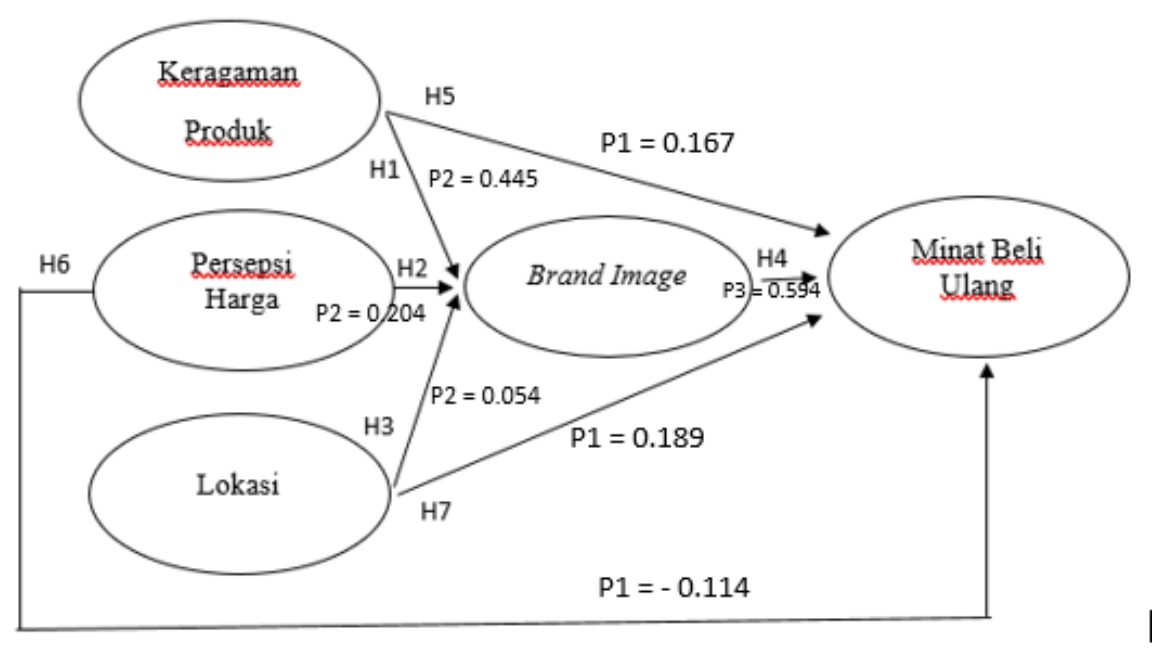

a. Pengaruh Keragaman Produk (X1) terhadap minat beli ulang (Z) dengan dimediasi oleh brand image (Y):

Pengaruh mediasi yang ditunjukkan oleh perkalian koefisien (P2 x P3) untuk X1 sebesar 0,264 signifikasi atau tidak diuji menggunakan Sobel test sebagai berikut :

$$
\begin{aligned}
& S p 2 p 3=\sqrt{p 3^{2} S p 2^{2}+p 2^{2} S p 3^{2}+S p 2^{2} S p 3^{2}} \\
& S p 2 p 3=\sqrt{0.594^{2} 0.076^{2}+0.445^{2} 0.115^{2}+0.076^{2} 0.115^{2}} \\
& S p 2 p 3=\sqrt{0.002038+0.002619+0.00007639} \\
& S p 2 p 3=\sqrt{0.004733249} \\
& S p 2 p 3=0.068799
\end{aligned}
$$

Berdasarkan SP2P3 dapat menghitung nilai t statistik pengaruh mediasi dengan rumus:

$t=\frac{P_{2} P_{3}}{S P_{2} S P_{3}}=\frac{0.264}{0.068799}=3.8373$

\section{E-ISSN: 2777-1156}

2021. Vol 5. No 1 
Fakultas Ekonomi, Universitas Cokroaminoto Yogyakarta

Nilai t tabel diperoleh dari tabel $t$ dengan tingkat kesalahan $\alpha(5 \%)$ dan derajat bebas $n$ $-\mathrm{k}=100-5=95$, didapat sebesar 1,99. Oleh karena itu $\mathrm{t}$ hitung (3.8373) $>\mathrm{t}$ tabel $(1,99)$ maka dapat disimpulkan bahwa ada pengaruh mediasi. Hasil ini juga menunjukkan bahwa secara tidak langsung keragaman produk mempunyai pengaruh yang signifikan terhadap minat beli ulang dengan dimediasi oleh brand image. Dengan kata lain, brand image secara signifikan dapat memediasi pengaruh keragaman produk terhadap minat beli ulang. Nilai koefisien pengaruh langsung sebesar 0.167 dan pengaruh tidak langsung 0,264 Sedangkan pengatuh total sebesar 0,431.

b. Pengaruh Persepsi Harga (X2) terhadap minat beli ulang (Z) dengan dimediasi oleh brand image $(\mathrm{Y})$

Pengaruh mediasi yang ditunjukkan oleh perkalian koefisien (P2 x P3) untuk X2 sebesar 0,1212 signifikasi atau tidak diuji menggunakan Sobel test sebagai berikut :

$$
\begin{aligned}
& S p 2 p 3=\sqrt{p 3^{2} S p 2^{2}+p 2^{2} S p 3^{2}+S p 2^{2} S p 3^{2}} \\
& S p 2 p 3=\sqrt{0.594^{2} 0.084^{2}+0.204^{2} 0.115^{2}+0.084^{2} 0.115^{2}} \\
& S p 2 p 3=\sqrt{0.00249+0.00055+0.0000933} \\
& S p 2 p 3=\sqrt{0.003133} \\
& S_{p 2 p 3}=0.055976
\end{aligned}
$$

Berdasarkan SP2P3 dapat menghitung nilai t statistik pengaruh mediasi dengan rumus:

$$
t=\frac{P_{2} P_{3}}{S P_{2} S P_{3}}=\frac{0.1212}{0.055976}=2.1675
$$

Nilai t tabel diperoleh dari tabel $t$ dengan tingkat kesalahan $\alpha(5 \%)$ dan derajat bebas $n$ $-\mathrm{k}=100-5=95$, didapat sebesar 1,99. Oleh karena itu $\mathrm{t}$ hitung (2.1675)>t tabel $(1,99)$ maka dapat disimpulkan bahwa ada pengaruh mediasi. Hasil ini juga menunjukkan bahwa secara tidak langsung persepsi harga mempunyai pengaruh yang signifikan terhadap minat beli ulang dengan dimediasi oleh brand image. Dengan kata lain, brand image secara signifikan dapat memediasi pengaruh persepsi harga terhadap

\section{E-ISSN: 2777-1156}


Fakultas Ekonomi, Universitas Cokroaminoto Yogyakarta

minat beli ulang. Nilai koefisien pengaruh langsung sebesar -0.114 dan pengaruh tidak langsung 0.1212 Sedangkan pengatuh total sebesar 0,0072.

c. Pengaruh Lokasi (X3) terhadap minat beli ulang (Z) dengan dimediasi oleh brand image (Y)

Pengaruh mediasi yang ditunjukkan oleh perkalian koefisien (P2 x P3) untuk X3 sebesar 0,0321 signifikasi atau tidak diuji menggunakan Sobel test sebagai berikut :

$$
\begin{aligned}
& S p 2 p 3=\sqrt{p 3^{2} S p 2^{2}+p 2^{2} S p 3^{2}+S p 2^{2} S p 3^{2}} \\
& S p 2 p 3=\sqrt{0.594^{2} 0.053^{2}+0.054^{2} 0.115^{2}+0.053^{2} 0.115^{2}} \\
& S p 2 p 3=\sqrt{0.000991+0.000386+0.00003715} \\
& S p 2 p 3=\sqrt{0.001067} \\
& S p 2 p 3=0.032662
\end{aligned}
$$

Berdasarkan SP2P3 dapat menghitung nilai t statistik pengaruh mediasi dengan rumus:

$$
t=\frac{P_{2} P_{3}}{S P_{2} S P_{3}}=\frac{0.0321}{0.032662}=1.00
$$

Nilai t tabel diperoleh dari tabel t dengan tingkat kesalahan $\alpha(5 \%)$ dan derajat bebas $n$ $-\mathrm{k}=100-5=95$, didapat sebesar 1,99. Oleh karena itu $\mathrm{t}$ hitung $(1.00)<\mathrm{t}$ tabel $(1,99)$ maka dapat disimpulkan bahwa tidak ada pengaruh mediasi. Hasil ini juga menunjukkan bahwa secara tidak langsung persepsi lokasi tidak mempunyai pengaruh yang signifikan terhadap minat beli ulang dengan dimediasi oleh brand image. Dengan kata lain, brand image secara signifikan tidak dapat memediasi pengaruh lokasi terhadap minat beli ulang. Nilai koefisien pengaruh langsung sebesar 0.189 dan pengaruh tidak langsung 0.0321 Sedangkan pengatuh total sebesar 0,2211.

\section{PEMBAHASAN}

\section{Pengaruh Keragaman Produk terhadap Brand Image}

Berdasarkan hasil hipotesis yang diketahui dalam penelitian ini menunjukkan bahwa nilai signifikansi keragaman produk terhadap brand image adalah $0,000<0,05$ artinya

E-ISSN: 2777-1156

2021. Vol 5. No 1 


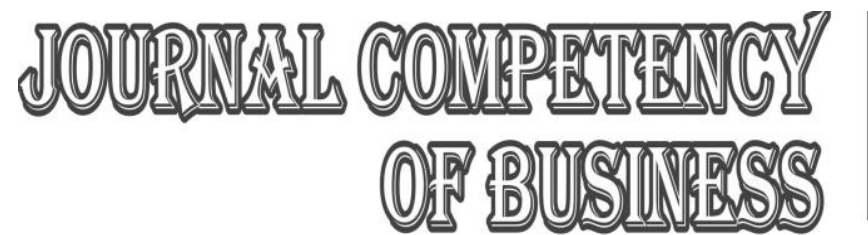

Fakultas Ekonomi, Universitas Cokroaminoto Yogyakarta

keragaman produk berpengaruh signifikan terhadap brand image. Hal ini tergolong keragaman produk berpengaruh postif terhadap brand image.

\section{Pengaruh Persepsi Harga terhadap brand image}

Berdasarkan hasil hipotesis yang diketahui dalam penelitian ini menunjukkan bahwa nilai signifikansi Persepsi Harga terhadap brand image adalah $0,017<0,05$ artinya persepsi harga berpengaruh signifikan terhadap brand image. Hal ini tergolong persepsi harga berpengaruh postif terhadap brand image.

\section{Pengaruh Lokasi terhadap Brand Image}

Berdasarkan hasil hipotesis yang diketahui dalam penelitian ini menunjukkan bahwa nilai signifikansi Lokasi terhadap brand image adalah 0,316>0,05 artinya Lokasi tidak berpengaruh signifikan terhadap brand image. Hal ini tergolong Lokasi tidak berpengaruh postif terhadap brand image.

\section{Pengaruh Brand Image terhadap Minat Beli Ulang}

Berdasarkan hasil hipotesis yang diketahui dalam penelitian ini menunjukkan bahwa nilai signifikansi brand image terhadap minat beli ulang adalah $0,000<0,05$ artinya brand image berpengaruh signifikan terhadap minat beli ulang. Hal ini tergolong brand image berpengaruh postif terhadap minat beli ulang.

\section{Pengaruh Keragaman Produk terhadap Minat Beli Ulang}

Berdasarkan hasil hipotesis yang diketahui dalam penelitian ini menunjukkan bahwa nilai signifikansi keragaman produk terhadap minat beli ulang adalah 0,098>0,05 artinya keragaman produk tidak berpengaruh signifikan terhadap minat beli ulang. Hal ini tergolong keragaman produk tidak berpengaruh postif terhadap minat beli ulang.

\section{Pengaruh Persepsi Harga terhadap Minat Beli Ulang}

E-ISSN: 2777-1156 


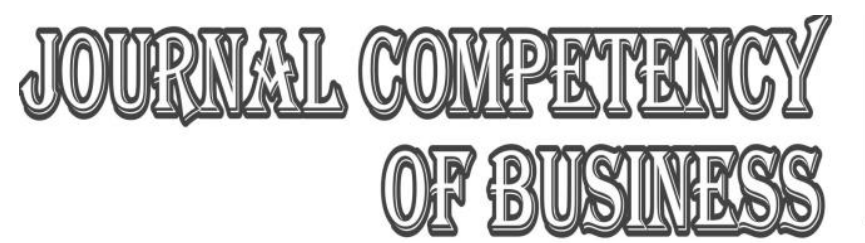

Fakultas Ekonomi, Universitas Cokroaminoto Yogyakarta

Berdasarkan hasil hipotesis yang diketahui dalam penelitian ini menunjukkan bahwa nilai signifikansi persepsi harga terhadap minat beli ulang adalah $0,245>0,05$ artinya persepsi harga tidak berpengaruh signifikan terhadap minat beli ulang. Hal ini tergolong persepsi harga tidak berpengaruh postif terhadap minat beli ulang

\section{Pengaruh Lokasi terhadap Minat Beli Ulang}

Berdasarkan hasil hipotesis yang diketahui dalam penelitian ini menunjukkan bahwa nilai signifikansi lokasi terhadap minat beli ulang adalah $0,002<0,05$ artinya lokasi berpengaruh signifikan terhadap minat beli ulang. Hal ini tergolong lokasi berpengaruh postif terhadap minat beli ulang.

\section{KESIMPULAN DAN SARAN \\ KESIMPULAN}

1. Berdasarkan hasil uji statistik diketahui keragaman produk berpengaruh positif dan signifikan terhadap brand image di Rocket Chicken. Artinya semakin beragam keragaman produk yang dimiliki Rocket Chicken maka akan meningkatkan brand image.

2. Berdasarkan hasil uji statistik diketahui persepsi harga berpengaruh positif dan signifikan terhadap brand image di Rocket Chicken. Artinya semakin baik persepsi harga yang dimiliki Rocket Chicken maka akan meningkatkan brand image.

3. Berdasarkan hasil uji statistik diketahui lokasi tidak berpengaruh positif dan signifikan terhadap brand image di Rocket Chicken.

4. Berdasarkan hasil uji statistik diketahui brand image berpengaruh positif dan signifikan terhadap minat beli ulang di Rocket Chicken. Artinya semakin baik brand image yang dimiliki Rocket Chicken maka akan meningkatkan minat beli ulang.

5. Berdasarkan hasil uji statistik diketahui keragaman produk tidak berpengaruh positif dan signifikan terhadap minat beli ulang di Rocket Chicken.

E-ISSN: 2777-1156

2021. Vol 5. No 1 


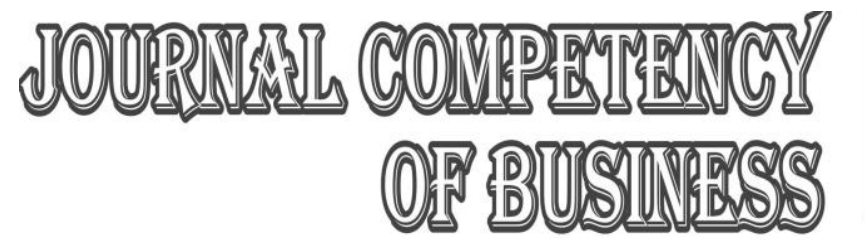

Fakultas Ekonomi, Universitas Cokroaminoto Yogyakarta

6. Berdasarkan hasil uji statistik diketahui persepsi harga tidak berpengaruh positif dan signifikan terhadap minat beli ulang di Rocket Chicken

7. Berdasarkan hasil uji statistik diketahui lokasi berpengaruh positif dan signifikan terhadap minat beli ulang di Rocket Chicken. Artinya semakin baik lokasi yang dimiliki Rocket Chicken maka akan meningkatkan minat beli ulang.

\section{SARAN}

1. Bagi Penelitian Kedepan

Dengan keterbatasan dalam penelitian ini, diharapkan peneliti yang akan datang dapat mengembangkan lebih variabel-variabel lain selain, Keragaman Produk, Persepsi Harga, dan Lokasi dalam penelitiannya.

2. Bagi Rocket Chicken

Bedasarkan kesimpulan dari penelitiaan yang telah dilakukan peneliti menunjukkan bahwa Keragaman Produk dan Persepsi Harga berpengaruh positif dan signifikan terhadap brand image Rocket Chicken. Sehingga Rocket Chicken sangatlah penting untuk membangun keragaman produk dan persepsi harga yang baik dimata pembeli. Selanjutnya hal tersebut akan meningkatkan minat beli ulang untuk membeli makanan dan minuman di Rocket Chicken, sehingga Rocket Chicken akan mampu bersaing dengan franchise sejenis lainnya.

\section{DAFTAR PUSTAKA}

Agustina, Fitra. 2017. Analisis Pengaruh Experiential Marketing Dan Kualitas Pelayanan Terhadap Minat Beli Ulang Pada Toko Oenta Di Tenggarong. Program Studi Kewirausahaan. Fakultas Ekonomi dan Bisnis.

Ananda, dkk. 2015. Pengaruh Sosialisasi Perpajakan, Tarif Pajak, Dan Pemahaman Perpajakan Terhadap Kepatuhan Wajib Pajak (Studi Pada UMKM Yang Terdaftar Sebagai Wajib Pajak Di Kantor Pelayanan Pajak Pratama Batu). Jurnal Perpajakan (JEJAK). Vol 6 No 2. Hal 1.

E-ISSN: 2777-1156 


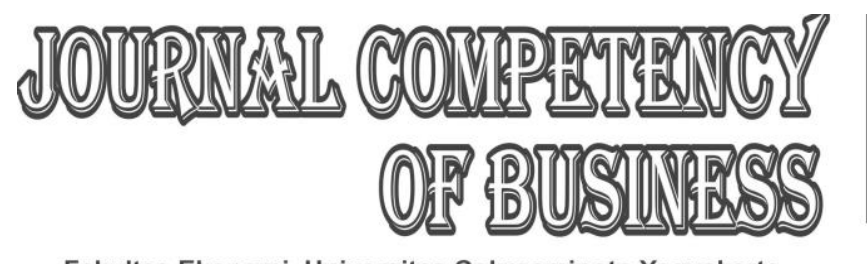

JI. Perintis Kemerdekaan,

Gambiran, Umbulharjo

Yogyakarta 55161

Telp : 0274 - 372274

Faks : $0274-4340644$

Fakultas Ekonomi, Universitas Cokroaminoto Yogyakarta

Heizer, Jay and Render Barry, (2015), Manajemen Operasi : Manajemen Keberlangsungan dan Rantai Pasokan, edisi 11, Salemba Empat, Jakarta.

Henry Simamora, 2010, Manajemen Sumber Daya Manusia, Gramedia, Jakarta

Hidayat, Hotman Makmur. (2017). Pengaruh Suasana Toko Dan Lokasi Terhadap Minat Beli Ulang Konsumen Di. Ud. Naysila Toys Simpang Skpd., 1-10.

Kotler, Philip dan Armstrong, Gary. 2012. Principles of Marketing. New Jersey: Prentice Hall.

Kotler, dan Keller. (2012). Manajemen Pemasaran. Edisi 12. Jakarta: Erlangga

Kurniawan. Adi, 2012. Keputusan Pembelian dan Faktor Loyalitas Pelanggan Dalam Pemasaran Online. Mustika Utama. Surakarta.

Lee, Simon ; Abdou Illia, Lawson-Body, Assion.2011. Perceived Price of Dynamic Pricing, Journal of Industrial Management + Data system

Nurhayati dan W. W. Murti. 2012. “Analisis Faktor-Faktor Yang Mempengaruhi Minat Beli

Ulang Masyarakat Terhadap Produk Handphone:. Jurnal UnimusVol. 8 No.2, 2012.

Rocket Chicken Indonesia, 2019, Tentang Rocket Chicken, https://rocketchicken.co.id/about/ (Diakses 27 Oktober 2020)

Savitri, I. A., \& Wardana, I. M. (2018). PENGARUH CITRA MEREK, KUALITAS PRODUK DAN PERSEPSI HARGA TERHADAP KEPUASAN DAN NIAT BELI ULANG. E-Jurnal Manajemen Unud, 5748-5782.

Supranto. Limakrisna, Nandan, 2011, Perilaku Konsumen dan Strategi Pemasaran. Mitra Wacana Media: Jakarta

Tjiptono \& Chandra, G. ( 2012). Pemasaran Strategik. Edisi Kedua. Yogyakarta: ANDI

Toncar, M. F., Alon I., Misati E, (2010), The Importance of Meeting Price Expectations, Journal of Product and Brand Management, Vol. 19 Iss: 4 pp. 295-305.

Biodata:

E-ISSN: 2777-1156

2021. Vol 5. No 1 


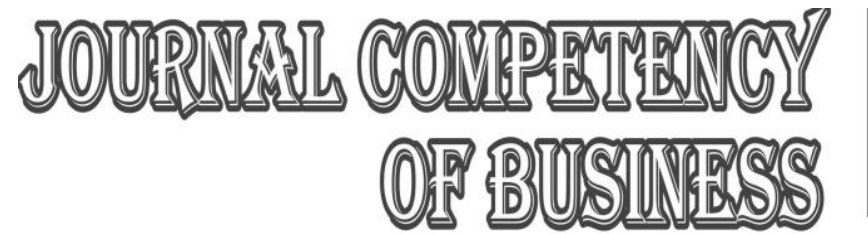

Fakultas Ekonomi, Universitas Cokroaminoto Yogyakarta

Ignatius Soni Kurniawan adalah dosen tetap pada Program Studi Manajemen Universitas Sarjanawiyata Tamansiswa Yogyakarta. Saat ini berstatus sebagai wakil dekan 1 dan memiliki minat penelitian pada bidang manajemen.

Risang Nagar adalah mahasiswa tingkat akhir di Program Studi Manajemen Universitas Sarjanawiyata Tamansiswa Yogyakarta. Minat studinya adalah dibidang manajemen keuangan. Prestasi diluar akademik adalah dibidang olah raga pencak silat.

E-ISSN: 2777-1156

2021. Vol 5. No 1 